\title{
Exploring the Managerial Dynamics in a Turbulent Context: The Reaction of SMEs' Leaders
}

\author{
Eliane Khalifé \\ Saint Joseph University of Beirut \\ Bernard de Montmorillon \\ Paris Dauphine University-PSL
}

\begin{abstract}
Small and medium enterprises constitute the bulk of the Lebanese economic fabric. Over the past decades, the managers of these SMEs have played a pivotal role in the survival of their businesses. This research aims at understanding how these managers manage to survive in a turbulent context marked by perpetual changes that are almost constantly renewing themselves, by showing how, in such an environment, they manage to mobilize resources and skills and deploy dynamic capacities in order to develop efficient and sustainable practices. The results of qualitative research of the exploratory type are intended to present researchers with a "reaction model" that, in a similar context, could enlighten SME leaders on the managerial performance required.
\end{abstract}

Keywords: SME, leader, turbulent context, management practices, Lebanon

\section{INTRODUCTION}

In constantly changing environments, companies suffer direct consequences that affect their strategies and performance (Smart and Vertinsky, 1984). These effects, which induce new managerial behaviours, lead leaders ${ }^{1}$ to monitor and integrate the "environment" dimension into their decision-making in order to survive, safeguard their place in the market and develop (Lesca, 2008; Kotler et al., 2014). They are compelled to be attentive and reactive in their daily practices, which enables them to divert threats and/or transform them into opportunities (Brouard, 2007). This observation, which concerns large firms, is also true for SMEs (Crutzen and Van Caillie, 2010). Saporta's (1986) analysis, carried out more than thirty years ago and which considered that the survival of the SME is intimately linked to its mostly uncertain environment, is still valid today with a two-way reading. According to Torrès (2002), the size of the SME gives it organizational flexibility as well as reactivity in decision-making, which favours the seizing of emerging market opportunities (Julien, 1997; Julien and Carrier, 2002). On the other hand, Raymond and St-Pierre (2005) stipulate that in an uncertain context, the survival of the SME is threatened. Indeed, such a context requires reactive decisions despite the limited information and resources available to the firm. These studies, which confirm the link between the survival of the SME and the surrounding context, do not focus on current management practices.

The Lebanese context is unique. Fifteen tumultuous years of civil war (from 1975 to 1990) followed by Israeli invasions and internal conflicts rooted in a system of confessional pluralism. This system, linked 
to both the history and the geographical situation of the country, is based on the official recognition by the state of 18 religious communities. In addition, there is a complex regional situation marked by the current war in Syria [March 2011 and until now] (Corm, 2004). All these disturbances have not occurred without direct impact on the country, which is in an endemic state of political, economic and social instability (Desquilbet, 2007; Couland, 2005). The definition of the SME, which constitutes the backbone of the Lebanese economy, depends on the national context in which it evolves (Zinnbauer et al., 2009; Ramadan and Levratto, 2011). We retain the one adopted by the German Agency for International Cooperation (GTZ) in a study ${ }^{2}$ carried out in 2007, which gives the following classification for the Lebanese SME: the category of very small enterprises is made up of firms that employ less than 5 persons. The category of small enterprises is made up of companies that employ between 5 and 49 people. The category of medium enterprises consists of enterprises that employ between 50 and 200 persons. In this study, the last two definitions were used ${ }^{3}$. The management of these companies has peculiarities that are related to the Lebanese culture. This management, which mainly leans towards the informal and is subject to controversies, has hardly raised enough interest among researchers (Hamdan, 2004), although a considerable number of SME managers have been able, in such a context, to conquer foreign markets (Levratto and Ramadan, 2009). Moreover, a large number of SMEs are only growing by showing a remarkable capacity for resilience, based, according to Choucair (2012) and Abi-Samra (2010), on specific management practices. Taking into account the fact that small business leaders are inclined to easily evoke the causes that are at the root of their organizations' success and that they consider to be a personal victory (Weitzel and Jonsson, 1989), an investigation conducted among these leaders will attempt to identify and analyze these practices.

Our article reinforces the literature that suffers from a lack of empirical anchoring (Le Boulaire and Retour, 2008) as well as data that indicate to managers of small and medium enterprises how to manage effectively (Sadler-Smith et al., 2003). It presents, in the form of a model, a specific combination of resources, which, when articulated together, help the SME manager to withstand a turbulent context. By rethinking a classical model based on the work of resource theory and focusing on firms of a certain size (Barney, 1991), this research focuses on SMEs and approaches their managers in a dynamic process. Thus, taking into account the specificity of Lebanese SMEs which have shown a remarkable resilience (ElKhoury, 2011) and the particularity of SME managers' actions in such a context, this study aims at answering the following question: "What are, in a turbulent context, the effective and sustainable managerial practices through which SME managers manage to reinforce the resilience of their firms? ».

In order to answer this question, we conducted a case study among fifteen Lebanese SME managers. In order to highlight the link between the manager's practices and the turbulent context, we first studied the turbulence of the Lebanese context. Subsequently, we relied on a literature review on the leader's role within the SME as well as on the strategies elaborated from the dynamic resources, skills and capacities. These strategies are more likely to be relevant in changing environments, as the survival of organizations within the same environment depends on the resources they hold and mobilize for the provision of products and services (Foss and Ishikawa, 2007). Next, we described the methodological protocol followed. We presented, analyzed and interpreted the results before finally moving on to managerial discussion and conclusion.

\section{THEORETICAL FRAME OF REFERENCE}

The turbulent context is a complex, particularly agitated context, the elements of which are continually changing (Emery and Trist, 1965). The literature on this topic has focused on three main attributes that describe it. It is an environment subject to a succession of rapid changes that are almost constantly changing and unpredictable (Cameron et al., 1987; Ansoff and McDonnell, 1990; Gueguen, 2001). In Lebanon, the environment is constantly marked by rapid and profound changes. In addition to the fifteen years of civil war that have torn the country apart, Lebanon is struggling in a fragile context manifested by an almost chronic state of interlocking crises of all kinds: political, economic and social (Corm, 2004). The inadequacy of the political system, the decay of institutions, and the absence of appropriate and in-depth

Journal of Applied Business and Economics Vol. 23(5) 2021101 
economic reforms only aggravate the situation (Fayad, 2008). This context, described by El-Ezzi (2003) as specific and complex, has been affected by damage at all levels: considerable material damage, a large number of victims and 600,000 internally displaced persons, emigration of nearly a quarter of the population, material degradation of basic infrastructure, a serious deterioration in the productive capacities of the economy and a weakening of the situation of private enterprises (Labaki and Rjeily, 1993). In this environment where changes are frequent and follow one another accompanied by poor control of uncertainty, turbulence is intense (Salloum, 2015).

To describe the SME, the six characteristics of Julien's (1997) factual model will serve as a reference. These elements, validated by most of the work in management science, are: the central role of the leader, the flexible organizational structure, the simplicity of the coordination mechanisms and the information system, the lack of resources and the weakness of skills.

We will address these elements by looking specifically at the leader's practices. Indeed, the concept of SME refers to a specific dynamic (Levratto, 2009) that is distinguished by the leader's daily management practices, specifically in unstable environments. These are mainly the leader's expectations of employees, their mobilization, strong interpersonal relationships and ease of communication (Barzi, 2011; St-Pierre et al., 2003). When these actions are adequately mobilized in the face of pervasive uncertainties, they enable the leader to quickly renew his tactics and strengthen the agility of his company, thus enabling the SME to demonstrate greater resilience (Barzi, 2011; Sherehiy and Karwowski, 2014; Sull, 2010).

Pinel and Robert (2009, p.71) have defined resilience, and we will retain their approach, as "the ability of a system to maintain or restore an acceptable level of functioning despite disturbances (...)". In the SME context, this capacity is deployed through the skills, intuition, versatility and profile of the leader (Lee and Tsang, 2001; Abaaoukide and Bentaleb, 2011; Durand, 2006; Sogbossi, 2012). For these authors, the same situation is perceived and interpreted differently depending on the leader's profile. Subsequently, the decision-making process varies and can be explained through the personality of the SME manager, his experience (Alaoui et al., 2008; Lefebvre, 1991; Marchesnay, 2000; Jaouen, 2010) and his ability to influence employees and build loyalty (Peretti and Swalhi, 2007). For example, a paternalistic manager makes rather traditional decisions (Raveleau, 2007; Bryan and Farrel, 2009; Meier and Pacitto, 2007), whereas a more knowledgeable manager relies on innovation in his decisions (Dugré, 2011; Beyer, 2010). Moreover, the leader's behaviour blends in with the SME's strategy, in the case where his power comes essentially from his leadership (Antonakis et al., 2004), and this along two lines. In the first, called dialogical and maintained between him and his company, two logics, one individual and the other collective, are combined (Fonrouge, 2002). The second, known as internal proximity, is based on a loosely structured hierarchy based on informal communication between internal actors and allows the manager to maintain his hold on the firm and its evolution (Torrès and Jaouen, 2008). In addition, the notion of external proximity allows the manager to better understand his environment and subsequently be able to modify part of it. In fact, through his or her business relational network, the manager acquires a privileged mode of access to certain specific resources (Chabaud and Sammut, 2016; Puthod and Thévenard-Puthod, 2006). This creates a competitive advantage for the SME and strengthens its resilience (Marchesnay, 2008; Martin, 2008).

Coutu (2002) argues that one of the aspects of managing a resilient organization is knowing how to take advantage of resources to tinker with new solutions to unusual situations encountered. Note that resources can be tangible, intangible, financial or human (Prévot et al., 2011). This aspect, which is consistent with the definition of resources as assets "that an organization holds or is capable of mobilizing" (Johnson et al., 2011, p.105), leads to an analysis of organizations' managerial practices through their deployment. For his part, Andrieux (2005) asserts that the leader's ability to develop new configurations for using these resources as quickly as possible contributes to consolidating the resilience of his organization and providing it with a structure that is favourable to its survival and growth. The mismatch in terms of resources between the present and the ambitious future creates a tension in the executive that creates a problem-solving dynamic within the company (Fauvy, 2009).

We continue the analysis by considering core competencies as the "activities through which an organization uses or deploys its resources" (Johnson et al., 2011, p.105); such mobilization is essential to 
ensure the firm's good management in an unusual situation of change (Hamel and Prahalad, 1995). These competencies are qualified as key when they are of value to the organization's clients, thus enabling it to differentiate itself from its competitors (Johnson et al., 2011). They are part of organizational routines and are the result of collective learning (Saives et al., 2011). Following periods of uncertainty, this learning makes it possible to better prepare for the future of the company (Altintas and Royer, 2009). Thus, in a turbulent context, leaders must know how to mobilize, coordinate and integrate skills into goods and services that generate value in order to benefit from market opportunities and neutralize environmental threats (Ulrich et al., 2008). This astute combination, which it is appropriate to identify, is similar to the strategic capacity of the company (Barney, 1991; Johnson et al., 2011), which evolves over time. This is the concept of dynamic capabilities (DC), which explains the organization's ability to recompose, transform and reconfigure this combination to adapt to a changing environment (Teece, 2007; Mercuri and Raïs, 2010).

This literature review leads us to formulate our problem as follows: Taking into account the specificity of the Lebanese environment, the objective of this research is to understand how SME managers manage, through their managerial practices, to reinforce the resilience of their companies, and this by mobilizing resources and skills and by reconfiguring the CDs in the context in which they work. This issue is broken down into exploration elements in Table 1, which constitutes the reference framework for the research. This table, which served as a support for the data collection and analysis, groups together four questions that the field investigation will enable us to answer.

\section{TABLE 1 THE RESEARCH TERMS OF REFERENCE}

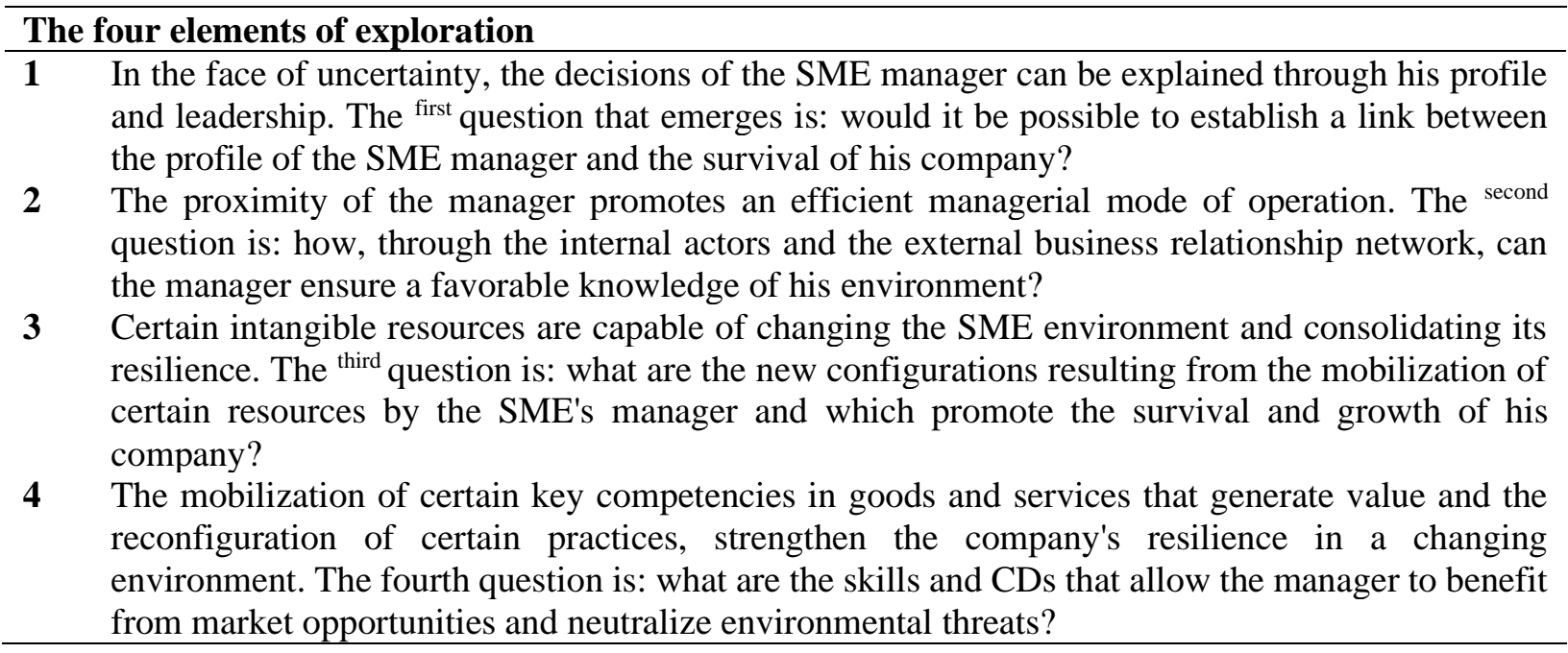

\section{METHODOLOGICAL PROTOCOL}

The conceptualization of the problem resulted in a reference framework made up of four elements of exploration from the literature (Mucchielli, 2005). From this framework, the main themes, each of which corresponded to a specific level of knowledge, were developed. They contributed to the construction of the interview guide (Appendix 1) with previously formulated questions that guided our interviews in the data collection. We used ${ }^{4}$ potential indicators identified in the literature to develop and formulate these questions (Lamoureux, 1995; De Peretti et al., 2013). Subsequently, comparing the data collected with existing theories enabled us to understand and explain the managerial practices of Lebanese leaders that have proven effective and underpin the resilience of their organizations.

This research is part of a qualitative, exploratory approach based on an interpretive phenomenological methodology, which translates into a focus on the dynamic aspect of the research process (Smith and 
Osborn, 2003). The case study strategy was mobilized in the construction of the research object. This strategy, based on the uniqueness of each firm as well as on the Lebanese SME-manager symbiosis, allowed us to explore specific practices related to SME managers.

The sampling of the targeted SMEs was carried out in a reasoned and non-statistical manner. The SMEs were selected based on the disparity of several predetermined characteristics: manager profiles, workforce, location, industry sector, etc. The SMEs were selected on the basis of the disparity of several pre-determined characteristics: manager profiles, workforce, location, industry sector, etc. Thus, our study population includes 15 managers who, up to the date of the interview, have been able to cope with the crisis environment that has shaken the country for more than five decades. Appendix 2 presents a description of the interviewed executives, the location and size of the sampled SMEs as well as the different sectors of activity to which they belong. Semi-directive focused interviewing was the preferred qualitative data collection method. The data collected was processed as suggested by Bardin (2013) in four stages using content analysis with the use of the qualitative analysis software Weft QDA ${ }^{5}$.

- During the first stage, which is the preparation of the material, the 15 recorded interviews (I1, $\mathrm{I} 2, \ldots \mathrm{I} 15)$, were transcribed in full with line numbering and entered on a complete list of interviews to be analyzed.

- The second stage, the pre-analysis stage, consisted of two operations. The first operation consisted of a careful reading of the material to be analyzed. In the second operation, the unit of analysis chosen as the cutting rule was the "theme". A thematic analysis was therefore carried out, to identify standardised units of meaning whose presence and frequency of appearance are significant.

- The third step, that of coding the material, was the controlled operation of the analysis. The work process adopted for this purpose was the traditional method of manual cutting for the first six interviews, followed by the use of the software on which the work was transferred and completed. The operation of the material was carried out in two stages, namely coding and categorization ${ }^{6}$. During coding, the raw discourse data were broken down according to the idea, into units of meaning to be coded (Bardin, 2013). This operation led to a reorganization of the content of the discourse and its transformation into a fairly large number of codes (189). Subsequently, all coded verbatim that had similar meanings were grouped together and classified under a generic title, which reduced the number of codes (72) because some were removed or integrated into others. After decomposing the processed material, we proceeded to define the first categories following the categorization approach of Miles and Huberman (2003). At this stage we used great care to keep the analysis close to the text, refraining from any interpretation. To this end, we based ourselves on an analogical and progressive grouping of coded units of meaning with a common semantic character, under broader categories (Mayer and Deslauriers, 2000). Once the preliminary analysis grid was developed, the work was transferred to the Weft QDA, which allowed us to count the occurrences. This operation contributed to the development of the final analysis grid (see Appendix 4), which was mainly anchored in the reference framework by eliminating and/or grouping together certain categories that recorded an occurrence of zero or at the limit equal to one.

- The interpretation of the results, which was the fourth stage of this work, consisted in reproducing as faithfully as possible the results obtained following the application of the analysis grid that guided us in our analyses and discussions and allowed us to judge whether the data collected meet the points identified in the reference framework.

The data collected from the respondent interviews revealed common characteristics among all leaders and highlighted two sets of leaders who differed in specific traits: the first set included 7 leaders with a rather cautious leadership style and the second set included 6 leaders with a rather reactive leadership style. Two of the 15 leaders interviewed, however, oscillated between the two sets. The data collected was classified in the analysis grid into four components ${ }^{7}$. Each component, presented and analyzed below (Part 3 ), grouped together a number of themes that were subdivided into sub-themes and then into categories. 


\section{PRESENTATION AND ANALYSIS OF RESULTS}

The aim of this part is to discern the divergences or convergences of the data collected in the field with the scientific writings in order to associate, for each of the four components, the theoretical contributions and the field. Thus, the categories that represent each component from the analysis grid were illustrated by verbatim reports taken from the interviewees' speeches and accompanied by a count on the distribution of these interviewees in the two sets of conduct identified $(n=\ldots)$. With the aim of transforming the results into the language of the discipline, this process was for each theme supplemented by an analysis and interpretation nourished by feedback from the literature. For example, by analyzing below the first theme of the first component, the prudent and reactive behaviors of leaders (from the field) corresponded successively to the profiles of paternalistic and informed leaders (from the literature).

\section{The 1st Component: Decision-Making in a Turbulent Context}

The Lebanese leader, who in his decisions favors survival strategies, much more than those of development and growth, is anxious to reconcile the quality of decisions with the quantity of quick decisions. The decisions taken by this leader are detailed below.

\section{Acting Conditioned by the Personality of the Leader}

The managers who, during the coding stage, had a "prudent" conduct, ensure the survival of the SME through rather static practices, based on a wait-and-see attitude and delaying action. Those who had a "reactive" conduct, seek survival through dynamic practices oriented towards innovation. Table 2 shows this:

\section{TABLE 2}

\section{ACTING CONDITIONED BY THE PERSONALITY OF THE LEADER}

\begin{tabular}{ll}
\hline The Land & Verbatim \\
Prudent" driving $(\mathbf{n = 7})$ & "(...) it's better to wait, (...) it's more cautious..." I3/ L474-477. \\
Reactive" driving $(\mathbf{n = 6})$ & "We are trying to find suitable and immediate solutions, and so far we \\
& have succeeded, (...). " I8/L36-41.
\end{tabular}

This subdivision enriches the literature by showing that the "cautious" leader who avoids change corresponds to the profile of the "paternalistic leader", the "PL". This leader, who is rather a leader-owner, is conservative and prudent (Raveleau, 2007; Bryan and Farrel, 2009). On the other hand, the "reactive" manager, who is more of an employee manager, corresponds to the profile of the "informed leader", the "IL", who focuses on the search for new alternatives to support his or her company (Dugré, 2011; Beyer, 2010).

Use of a Personalized Relationship With Employees

The familiar relationship between the Lebanese leader and his employees facilitates information gathering and control. In addition to this, there is a physical proximity, woven through the senses and nourished by the Lebanese culture, with the actors both internally and externally. This closeness, is the basis of the optimization of the employees' performance, as shown in the verbatim below. 
TABLE 3

USE OF A PERSONALIZED RELATIONSHIP WITH EMPLOYEES

\section{The Land \\ Close, spontaneous and \\ informal relationships $(n=14)$}

Physical closeness woven

through the senses $(n=11)$

\section{Verbatim}

"I like to take a little tour (...) it's a way to control, to

supervise. I talk to them [employees] about anything

and everything, ...." I9/ L209-215.

...seeing us, shaking their hand, a friendly gesture on

the shoulder, etc.". All this is necessary (...)." I1/ L122-

126.

The relations of affective proximity, which are a continuation of the work of Torrès (2002), establish a dynamic of problem solving and strengthen the leader's hold on the company. As for the physical link, it joins the polysensory management of Torrès (2007) which substitutes the sensory capacities of the leader to the classical management tools.

\section{Use of the Manager's Personal Skills}

Intuition, versatility, innovation and flair are, for the Lebanese leader, as many indispensable skills to make decisions. Although at this level the subdivision of respondents into two sets is clear, however, versatility and intuition bring them all together. The context that surrounds the Lebanese manager, marked his personality and contributed to make him a strong person through hardships and easily able to cope. The integration of intuition in decision making, gives him a skill based on his experience and judgment. In addition, the "reactive" leader demonstrates creativity and a faculty to monitor the course of events. The "prudent" leader demonstrates the ability to mobilize resources judiciously and at the right time. The "prudent" leader relies on his or her "flair", which comes from the know-how of ancestral leaders. The verbatim statements in Table 4 bear witness to this:

TABLE 4

\section{USE OF THE LEADER'S PERSONAL SKILLS}

\begin{tabular}{|c|c|c|}
\hline The Land & Verbatim & \\
\hline $\begin{array}{l}\text { The leader is a person with a } \\
\text { variety of abilities }(n=11)\end{array}$ & $\begin{array}{l}\text { "Here, there is everything and that's what makes the } \\
\text { Lebanese businessman versatile (...) with a great } \\
\text { knowledge in almost every field. " I3/ L446-447. }\end{array}$ & 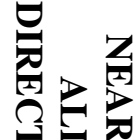 \\
\hline $\begin{array}{l}\text { The leader frequently uses } \\
\text { intuition to decide }(n=10)\end{array}$ & $\begin{array}{l}\text { "We base ourselves on intuition because we don't have a } \\
\text { concrete criterion that allows us to discern in such a } \\
\text { complex environment as ours. " I9/L136-140. }\end{array}$ & 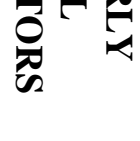 \\
\hline $\begin{array}{l}\text { The manager shows a } \\
\text { developed sense of creativity } \\
(\mathbf{n}=5)\end{array}$ & $\begin{array}{l}\text { "Lebanese is a well of ideas (...). Its concern is to always } \\
\text { find new solutions. " I7/ L123. }\end{array}$ & $\hat{\hat{A}}=$ \\
\hline $\begin{array}{l}\text { The manager actively and } \\
\text { continuously monitors the } \\
\text { course of events }(n=4)\end{array}$ & $\begin{array}{l}\text { "We're always on the alert (...), we can't sleep on our } \\
\text { victories, on our laurels, we have to be vigilant. "I I/ } \\
\text { L309-313. }\end{array}$ & 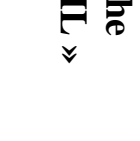 \\
\hline $\begin{array}{l}\text { The leader mobilizes } \\
\text { resources wisely } \\
(\mathbf{n}=5)\end{array}$ & $\begin{array}{l}\text { "By the force of things we become very fast (...) we try to } \\
\text { find quick emergency exits. "I14/ L48-51. }\end{array}$ & $\hat{\hat{A}}=$ \\
\hline $\begin{array}{l}\text { The leader returns to the } \\
\text { practices of his or her } \\
\text { predecessors }(n=6)\end{array}$ & $\begin{array}{l}\text { "(...) because we have the flair, it's in the family (...). " } \\
\text { I10/L 296-297. }\end{array}$ & \\
\hline
\end{tabular}


Running a Lebanese SME means being able to change "caps". This observation corroborates with the one reported in the literature, which considers that the versatility of the manager is an indispensable competence for the survival of the SME (Durand, 2006). The decision by intuition, favoured by the Lebanese manager, is a continuation of Sogbossi's work (2012). The author underlines that in a turbulent environment, the proliferation of several variables limits the scope of rational thinking in favour of intuitive decision making. Proactive decisions based on the speed of acting at the right time and with the minimum of resources are in line with Brouard's (2007) comments and highlight an entrepreneurial vision in "IL". In terms of the literature, the classic management mode of the "PL" is consistent with a traditional orientation. It is a leader centred on the values of the profession and the know-how of the ancestors, rather than on profit maximization (Meier and Pacitto, 2007; Jaouen, 2010).

\section{The 2nd Component: Managerial Practices Vis-a-Vis Partners}

At a time when the environment is putting him to the test, the Lebanese leader never tires of mobilizing actions through the network that surrounds him: employees, customers and partners in the business.

\section{Optimal Use of Employee Performance}

The Lebanese leader opts for the versatility of the employees which, according to him, limits recruitment, reduces the turnover rate and motivates the present elements. Moreover, the emigration of talents pushes him to reinforce the retention efforts with the only difference that these efforts are for the "IL" oriented towards qualified employees, while for the "PL", they are oriented towards rather dedicated employees. Table 5 shows an excerpt of verbatim reports on this subject.

\section{TABLE 5}

\section{MAXIMIZING EMPLOYEE PERFORMANCE}

\section{The Land \\ The leader advocates the versatility of the human element $(n=13)$}

\section{Manager retains qualified employees $(\mathbf{n}=6)$}

\section{Leader retains dedicated employees $(n=5)$}

\section{Verbatim}

"It's the versatility we prefer. The employee becomes more resourceful, more responsible and also more efficient because he understands all the systems, (...) This leaves him a certain margin for creativity." I2/ L401-414.

"When there is an employee who distinguishes himself from others by his competence, we try to retain him, to motivate him more by increasing his salary, by giving him a bonus,..." I8/L161-165.

"We try to invest in dedicated people who are not necessarily the best because they are the ones who stay, (...)." I12/ 154-156.
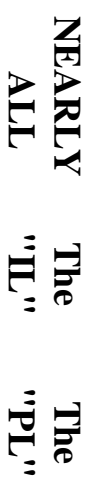

The literature agrees with these results and considers that the versatility of SME employees is a basic skill, which allows the human element to cope with change. The loyalty efforts made by managers are manifested through two orientations (Peretti and Swalhi, 2007): one relational, which is prominent in the "PL", and another of efficiency, which characterizes the "IL".

\section{Reaching Customer Satisfaction}

The manager's relationships with his clients are long-lasting and deep. The manager does not hesitate to make concessions and submit to their conditions even if he considers them illogical. The "IL" deploys his efforts to improve the quality of the offer in order to gain the loyalty of new customers. However, the "PL" is consolidating the refocusing on its traditional customers. Table 6 presents an excerpt of verbatim reports on this subject. 
TABLE 6

ACHIEVING CLIENT SATISFACTION

\begin{abstract}
The Land
The manager improves the quality of his products in order to win new customers $(\mathbf{n}=5)$

The manager consolidates the refocusing on his traditional customers $(n=6)$
\end{abstract}

The manager submits to the conditions of his clients $(n=$
Verbatim

"...if you have a customer, especially a new one, (...) you have to guarantee a certain quality. Our products follow international standards and we rely on that a lot..." I14/ $\sum_{=}^{=}$ L356-361.

"(...) the company's relationship with its former customers, its service .... All this makes them [customers] more available and ready to help you in difficult times." I2/ 34-37.

"...we are obliged to do work outside of the normal schedule and at the same price, (...), take it or leave it." I11/ L470-475

14)

The literature shows that the "IL", who is more of a manager-employee, seeks the growth of the SME he manages, while the "PL", who is a manager-owner, is more concerned with its day-to-day survival (Kotler et al., 2014). The concessions, sometimes aberrant, evoked by the managers suggest a specific relationship between the Lebanese manager and his customers.

\section{Networking}

Friendly and professional relationships mobilized both between SMEs in the same profession allow the sharing of experiences and challenges, as shown in the verbatim in Table 7.

\section{TABLE 7}

\section{NETWORKING}

\begin{tabular}{|c|c|c|}
\hline The Land & Verbatim & \\
\hline $\begin{array}{l}\text { Leader maintains friendly } \\
\text { relationships with peers } \\
(\mathbf{n = 1 1})\end{array}$ & $\begin{array}{l}\text { "(...) our relationship with them [the colleagues] is rather } \\
\text { friendly, implicit agreements (...) if there is information I } \\
\text { pass on, this does not prevent us from finding ourselves on } \\
\text { the market, on offers, one against the other." I3/ L422-429. }\end{array}$ & 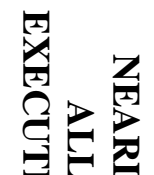 \\
\hline $\begin{array}{l}\text { Manager maintains formal } \\
\text { relationships with peers } \\
(\mathbf{n = 8})\end{array}$ & $\begin{array}{l}\text { "It's more of a professional relationship, very cordial. (...) } \\
\text { we can manage to further strengthen exchanges: raw } \\
\text { materials, products, knowledge (...)" I13/ L107-115. }\end{array}$ & $\sum_{\infty}$ \\
\hline
\end{tabular}

Peer relationships, when they are friendly, demonstrate among leaders, relationships that create value through the synergies generated (Puthod and Thévenard-Puthod, 2006). By joining Martin's (2008) work, they approach the relational network, reduce asymmetry in dependence on resources and contribute to increasing the organization's resilience.

\section{The 3rd Component: The Resources Essential to the Survival of the SME}

The resources needed to stay afloat in turbulent times differ according to what the two sets of identified leaders have to say. The "PL" agrees that human resources are more important, while the "IL" favours financial resources. 


\section{Activation of Human Resources}

The "savvy" manager seeks technically qualified, open-minded and initiative-oriented employees. On the other hand, the "paternalistic" manager values a staff with integrity and loyalty. Table 8 shows an excerpt from verbatim reports on this topic.

\section{TABLE 8 ACTIVATION OF HUMAN RESOURCES}

\begin{tabular}{|c|c|c|}
\hline The Land & Verbatim & \\
\hline $\begin{array}{l}\text { Manager seeks } \\
\text { creative employees } \\
(\mathbf{n = 5})\end{array}$ & $\begin{array}{l}\text { "We prefer someone who is always ready to play the game. (...) } \\
\text { open to change" I4/ L225-228. }\end{array}$ & $\stackrel{\bar{\beta}}{=}$ \\
\hline $\begin{array}{l}\text { Manager seeks } \\
\text { employees with } \\
\text { integrity and loyalty } \\
(\mathbf{n}=5)\end{array}$ & $\begin{array}{l}\text { "What matters to us is above all the human quality of our } \\
\text { employees (...) communication with others (...)." I2/ L201-204. }\end{array}$ & 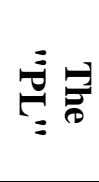 \\
\hline
\end{tabular}

The "IL" targets creative profiles with potential know-how. The "PL" pays particular attention to interpersonal skills (know-how) and seeks employees who are distinguished by communication skills (StPierre et al., 2003).

\section{Activation of Financial Resources}

The Lebanese leader expresses his mistrust of banks and tries to protect himself by the availability of liquidity. On the other hand, when the banks become an unavoidable means of financing, he enters into "cold" negotiations with them, as shown in the verbatim in Table 9.

TABLE 9

\section{ACTIVATION OF FINANCIAL RESOURCES}

\begin{tabular}{ll}
\hline $\begin{array}{l}\text { The Land } \\
\text { Manager distrusts banks } \\
(\mathbf{n = 9 )}\end{array}$ & $\begin{array}{l}\text { Verbatim } \\
\text { "Such an important resource is cash, (...) so that we can } \\
\text { continue to pay our costs, pay our employees, pay our } \\
\text { operating costs, (...)." I9/L 420-430. }\end{array}$ \\
$\begin{array}{l}\text { Manager begins "cold" } \\
\text { negotiations with banks } \\
(\mathbf{n = 8})\end{array}$ & $\begin{array}{l}\text { youn need them they would cost you three times as much (...) if } \\
\text { you negotiate them when there is no emergency it is much } \\
\text { better." I3/ L543-547. }\end{array}$ \\
\hline
\end{tabular}

The "cold" negotiations started with financial institutions are common and specific practices among Lebanese leaders. This result sheds light on the work carried out on the managerial maneuvers of SME managers in a turbulent environment.

\section{Activation of Practices Essential to the Survival of the SME}

The majority of managers agree on the rapprochement between international companies and local SMEs, which gives the latter a dynamism that reinforces its credibility. Moreover, the "IL" does not hesitate to explore foreign markets, while the "PL" prefers to move to another field of activity, without however, letting go of its basic field. Table 10 shows this: 
TABLE 10

ACTIVATION OF PRACTICES ESSENTIAL TO THE SURVIVAL OF THE SME

\begin{tabular}{|c|c|c|}
\hline The Land & Verbatim & \\
\hline $\begin{array}{l}\text { Manager enters into } \\
\text { agreements with } \\
\text { international companies } \\
(\mathbf{n}=\mathbf{1 3})\end{array}$ & $\begin{array}{l}\text { "(...), I think we need to make agreements with } \\
\text { international companies, which increases our } \\
\text { credibility." I8/ L120-124. }\end{array}$ & $\underset{⿱ 乛 龰}{\stackrel{Z}{Z}}$ \\
\hline $\begin{array}{l}\text { Executive explores markets } \\
\text { outside of borders }(n=6)\end{array}$ & $\begin{array}{l}\text { "(...) "we share the same clients", the Lebanese market } \\
\text { is microscopic, (...), we need to set foot abroad to } \\
\text { survive (...)" I15/ L300-304. }\end{array}$ & $\vec{\beta}_{=} \bar{\theta}$ \\
\hline $\begin{array}{l}\text { The manager moves to } \\
\text { another field of activity } \\
(n=4)\end{array}$ & $\begin{array}{l}\text { "(...) we diversified the work, my brother turned to real } \\
\text { estate, he was fed up with the problems of this job." I2/ } \\
\text { L226-231. }\end{array}$ & $\underline{\underline{\theta}}$ \\
\hline
\end{tabular}

This merger, described as an asymmetrical alliance, which has so far been little studied (Mercuri and Raïs, 2010), is of considerable benefit to the SME in terms of advice and room for manoeuvre. The exploration of foreign markets by "IL" is the result of an opportunity that arises, especially when the local market is saturated. By embarking on a new business, the "PL" begins a strategic diversification in order to reduce environmental risks.

The 4th Component: Skills in the Face of the Complexity of the Context

The skills that Lebanese leaders develop in the face of the complexity of the environment are partly similar and partly different.

The Reputation of the SME

The reputation of the SME is of major strategic importance, because it is mainly on it that the survival of the company depends. Relative verbatim is cited in Table 11.

\section{TABLE 11 REPUTATION OF THE SME}

\begin{tabular}{ll}
\hline The Land & Verbatim \\
The manager considers the & "The conditions of our survival (...) are linked to our \\
reputation of the SME, an & past and our reputation. " I13/ L217-222. \\
imperative for its survival & $\begin{array}{l}\text { "Our customers recognize us as a responsible and } \\
\text { reliable long-term partner, (...)." I6/ L633-635. }\end{array}$
\end{tabular}

The credibility of the SME, which enables it to gain the confidence of customers, supports Barney's (1991) comments that the reputation of the SME enables it to benefit from market opportunities and/or neutralize environmental threats.

Management Able to Mobilize Its Human Resources

The Lebanese leader remains the cornerstone of strengthening the creativity of his employees, thus creating a synergy within the SME. Thus, the "PL" motivates his employees by enhancing their sense of belonging while the "IL" motivates them by encouraging their creativity. The verbatim figures in Table 12 bear witness to this: 
TABLE 12

LEADER ABLE TO MOBILIZE HUMAN RESOURCES

\begin{tabular}{ll}
\hline The Land & $\begin{array}{l}\text { Verbatim } \\
\text { Leader encourages } \\
\text { employee creativity }(\mathbf{n = 4 )}\end{array}$ \\
$\begin{array}{l}\text { Manager values employees' } \\
\text { sense of belonging }(\mathbf{n}=\mathbf{6})\end{array}$ & $\begin{array}{l}\text { "The commitment of } \text { our employees strengthens } \text { us. }(. . .), \text { it } \\
\text { guarantees and will guarantee, through dead ends, the } \\
\text { survival of our company }(. . .) \text {, we care about them and they } \\
\text { care about us." I1/ L134-138. }\end{array}$ \\
\hline
\end{tabular}

The centrality of the leader comes from his or her leadership (Antonakis et al., 2004). It can be identified through two orientations: the first is human, found in the "PL" and favours emotions, and the second is productive, found in the "IL" and favours technicality.

\section{Projection Into the Future}

The managers agree on a permanent flexibility of their production process. The desire to ensure the sustainability of their business, remains their main reason for success. In addition, the "PL", by taking care of the daily routine, seeks to optimize its costs. On the other hand, the "IL", who aspires to a qualification as a "specialist", prefers to work on large projects. Table 13 shows this.

\section{TABLE 13}

\section{PROJECTION INTO THE FUTURE}

\section{The Land \\ The manager's planning horizon is distant $(n=6)$}

The manager's planning horizon is $\operatorname{short}(n=6)$

Manager invests in multifunctional equipment $(\mathbf{n}=8)$

\section{Verbatim}

"The image of the future, what we are trying to develop, is that of a company specialized in its field... " I6/L662-665.

"... We live from day to day, (...) big projects hardly exist. (...). I care about the present, the near future. " I10/L212-215.

"So our secret to success is to remain flexible. (...). Flexible means not being very heavy or highly specialized (...)." I4/ L182-189.
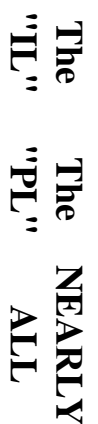

The problem-solving dynamics created by the mismatch in resources between the present and the future are weaker for "PL" than for "IL." The problem-solving dynamics created by the mismatch in resources between the present and the future are weaker for "PL" than for "IL". The latter, in aspiring to be called a "specialist", implements rather sustainable strategies. The flexibility of the production system is in line with the notion of flexible specialization (Saives et al., 2011), which, because of its adaptation to the SME, is an interesting contribution. Indeed, by equipping itself with multi-skilled equipment and personnel, the SME becomes a fertile breeding ground for innovation and reactivity.

\section{MANAGERIAL DISCUSSION AND CONCLUSION}

At the theoretical level, this article has collected the constructions of SME managers relating to a turbulent context, by mobilizing in a global way the approaches of management by resources and skills and by approaching them in a dynamic perspective. This mobilization provides an interesting configuration of strategic capacity based on new and easily applicable resource arrangements (Eisenhardt and Martin 2000). 
This is not obvious due to the lack of work on these approaches, which deal with a managerial problem specific to SMEs in a highly evolving environment.

The analysis of the results tends to show that Lebanese SMEs are "agile" SMEs. Subjected to the increased demand for responsiveness, they are capable of reacting to threats, surviving and growing in a context marked by rapid change (Sull, 2010; Barzi, 2011). The Lebanese leader is a leader who adopts strategies for overcoming turbulence based on strengthening the social bond between him/her and employees (Antonakis et al., 2004).

Furthermore, and following a review of previous studies, these results lead to two different findings. The first, which is in line with the literature, shows that "standard practices" do not exist (Lalonde, 2004). It highlights two profiles of leaders who ensure the survival of their firms through two different sets of actions: "paternalistic" leaders and "informed" leaders. The former, who are mostly owner-managers, flee risk and see their practices manifested through traditional measures. The latter, who in their majority are manager-employees, defy turbulence and see their actions based on innovation and the search for new alternatives. From this point of view, the status of the manager (company founder, owner, co-owner or employee), his personality, skills, willingness to take risks, education, attitude, endurance, ability to handle stress, etc. have an effect on his practices, and more specifically on the intensity of innovation and the propensity for growth of the SME he manages. The contribution at this level lies in the combination of practices that emerge for each set of managers. These two arrangements, summarized in Table 14, provide new avenues of research on the management practices of SME managers in a turbulent context.

\section{TABLE 14 \\ FRAMEWORK OF PRACTICES SPECIFIC TO EACH TYPE OF LEADER IN A TURBULENT CONTEXT}

\begin{tabular}{lll}
\hline & Paternalistic leader & Informed leader \\
\hline Status & Owner & Employee \\
\hline Looking for the & Survival of the SME & Growth of the SME \\
\hline Management Mode & Traditional Orientation & Entrepreneurial Orientation \\
\hline Employee Loyalty & Relational Orientation & Efficiency Orientation \\
\hline Employee Qualifications & Communication Profiles & Creative Profiles \\
\hline Adaptation to the Changing Market & Strategic Diversification & Exploration of New Markets \\
\hline Leadership Orientation & Human Element & Productivity \\
\hline Planning Horizon & Short Term & Medium and Long Term \\
\hline
\end{tabular}

The second observation, which constitutes an input to this study, enriches the literature on this subject. It highlights a set of management practices to which all managers agreed, regardless of their profiles, the type of firm, its size and the sector of activity to which it belongs. This contribution leads to managerial implications that aim to help managers concerned about ensuring the resilience of their organizations. These implications show that the reputation of the SME is an essential resource at the origin of its survival. They encourage managers to adopt an affective proximity management. This management optimizes the performance of the internal actors by enhancing their sensory capacities. In addition, these managers, who must be versatile, have an interest in often using their intuition in their decision making, which allows them to constantly rearrange their strategic arrangements. This versatility, which is also required for the employee, makes him or her capable of reacting adequately to any change. This work encourages SME managers to integrate flexible specialization into their production system. It is an organizational form that allows the production process to adapt quickly to any new change. It encourages them to enter into alliances, even asymmetrical ones, with international companies to strengthen the resilience of their businesses. It also encourages them to become part of a network led by a leading company (satellite companies), which provides competitive advantages to all companies. In order to counter the impact of the financial burden that weighs heavily on them in an unstable context, this study encourages SME managers to anticipate their 
needs for funds through negotiations initiated in advance with financial institutions. It also encourages them to focus on the client's needs, assuming that the client is always right. This action, considered by Levratto (2009) as a specific practice of SME management, proves to be routine within the Lebanese SME (Choucair, 2012). Finally, this research allowed us to observe that the availability of cash contributes to decrease the vulnerability of SMEs, especially since an unfavorable context never gives advance notice. The main managerial elements required in the face of environmental turbulence are summarized in Table 15.

\section{TABLE 15 \\ THE MAIN MANAGERIAL ELEMENTS REQUIRED IN THE FACE OF ENVIRONMENTAL TURBULENCE}

\begin{tabular}{ll}
\hline The Lebanese SME is an agile SME \\
\hline \multirow{3}{*}{ Management } & Proximity \\
\cline { 2 - 2 } Resources & Sensory management / by relevant and effective use of the senses \\
\hline & By walking around \\
\hline \multirow{5}{*}{ Reputation of the SME } & Cash and cash equivalents \\
\hline & Integration of intuition in the decision-making strategy \\
\cline { 2 - 2 } & Versatility \\
\hline \multirow{4}{*}{ Dynamic Capabilities } & Flexible production \\
\hline & Asymmetrical alliances with international companies \\
\cline { 2 - 2 } & Insertion in non-formalized networks of partners \\
\hline & $\begin{array}{l}\text { Concessions to customers / distrust of dependence on "big" } \\
\text { suppliers and/or customers }\end{array}$ \\
\cline { 2 - 2 } & Pre-negotiated loans with financial institutions \\
\hline
\end{tabular}

In conclusion, and by summarizing these determinants, the research has made it possible to develop a "reaction model" in Figure 1 that could enlighten SME managers working in a turbulent context on the managerial performance required. This model, which Helfat et al. (2009) believe it is wise to identify, seems to be an interesting contribution. Thus, the SME in a turbulent context is a structural system represented by a simple triangle. The leader, the master of the system, is located in the center. Because of the characteristics of the terrain (turbulence), this system needs deep foundations that will guarantee its solidity. These foundations bring together, under the aegis of three sets (Resources, Core Competencies and Dynamic Capacities), a multitude of practices based on human interactions and which allow us to understand how the SME, through a modeling of its resources and competencies, develops a process that reinforces its resilience. Finally, any structural system is subject to a process of erosion requiring permanent maintenance. Sensory management, management by waking around and proximity management ensure the resilience of this system. 


\section{FIGURE 1 \\ MODEL OF SME MANAGERS' REACTIONS TO A TURBULENT ENVIRONMENT}

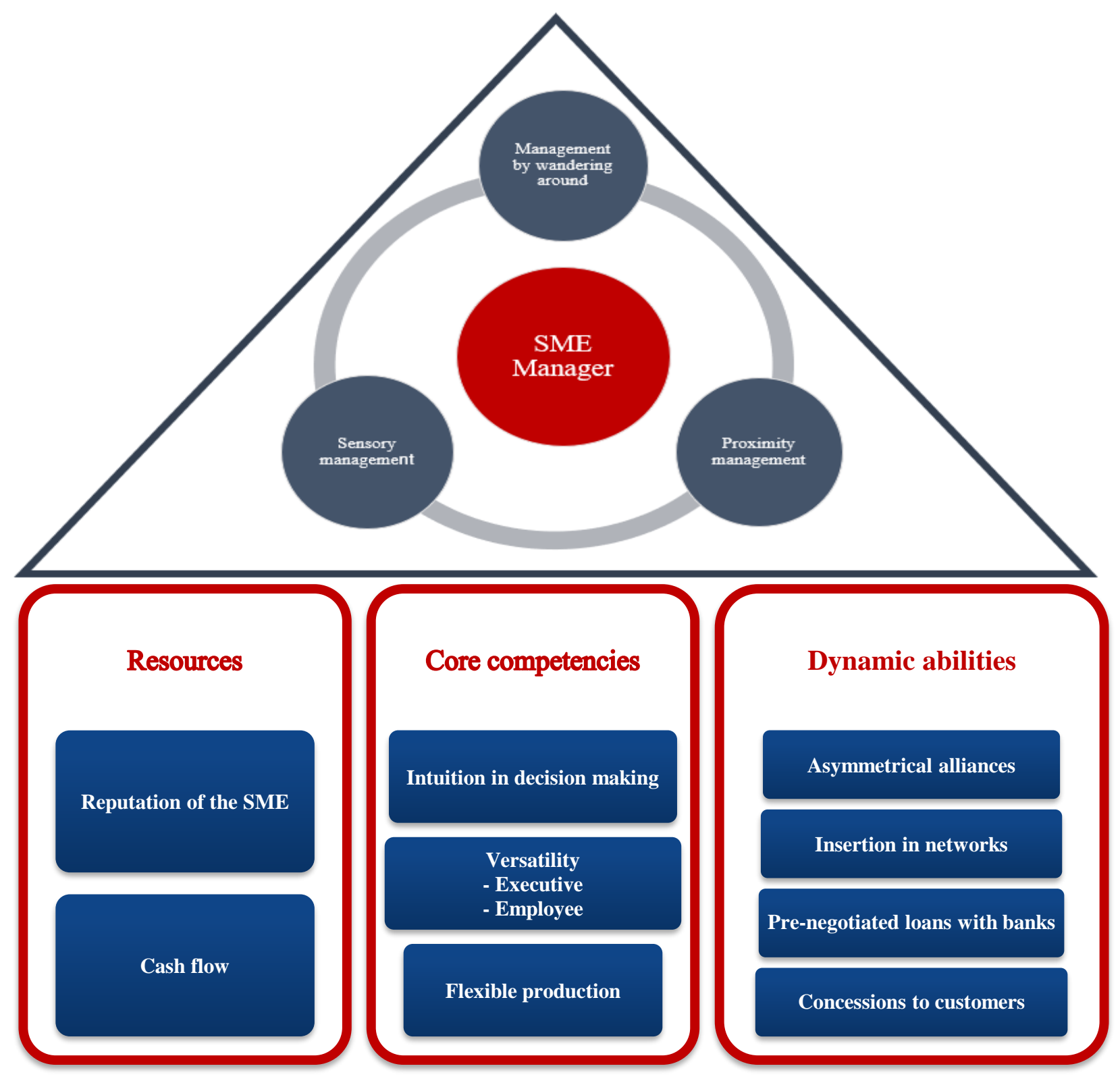

This configuration of resources, particularly intangible resources, brings together the manager, the SME and the context. According to Baum et al (2001), it offers a model of necessary action, easily mobilized and capable of better understanding the situation. However, this framework, although it is based on synergistic interactions, does not take into account all the factors and variables that shape the relationship between the SME manager and his environment and that can possibly be more complex (Pettersen et al., 2011). Moreover, this model, which is the result of exploratory research, does not fit into a logic of statistical generalization. Nevertheless, it does allow us to identify a set of reliable elements that deserve to be tested in subsequent research and on samples of managers of larger SMEs. Beyond these results, we can argue that the analysis of the Lebanese specificity clearly allowed to highlight the key characteristics of the managerial practices of the SME manager in a turbulent context; but haven't most of the contexts become so? 


\section{ACKNOWLEDGEMENT}

Translated \& Edited by American Publishing Services (https://americanpublishingservices.com/).

\section{ENDNOTES}

1. In this article, we use the terms leader and manager interchangeably.

2. $\quad$ "Situation Analysis and Intervention Strategy", Publication number: EF 03 - 2007, October 2007.

3. $\quad$ Refer to the "Workforce" column of the first table in Appendix 2.

4. An indicator is defined as a significant element in a set of data that makes it possible to assess a situation and is manifested by a dimension of a concept.

5. Free software available on Windows, Mac and Linux at: http //www.pressure.to/qda/

6. For a better understanding of the coding and categorization steps, refer to Appendix 3 .

7. For a better understanding of the subdivision into components, themes, sub-themes and categories, refer to the final analysis grid in Appendix 4.

\section{REFERENCES}

Abaaoukide, K., \& Bentaleb, C. (2011). La gestion de l'urgence dans les PME au Maroc: Perceptions et pratiques de gestion. Management et Avenir, (3), 143-163.

Abi-Samra, M. (2010). Lebanese emigration and its impact on the economy and development. Cahiers Des Migrations Internationales, (105). Publications of the International Labour Office, Geneva.

Alaoui, A., Aloulou, W., Fayolle, A., Andotra, N., \& Sundan, P. (2008, June). Antecedents and consequences of expanded marketing mix encounters across diverse entreprenurial profiles. Management Review, pp. 188-197.

Andrieux, M. (2005, July/August). Intangible capital: A sustainable value for SMEs. Revue Française de Comptabilité, 379, 33-36.

Ansoff, H.I., \& Mcdonnell, E.J. (1990). Implanting Strategic Management (2nd ed.). Prentice Hall.

Antonakis, J., Cianciolo, A.T., \& Sternberg, R.J. (2004). Leadership: Past, present, and future. The Nature of Leadership, pp. 3-15.

Bardin, L. (2013). L'analyse de contenu (2 edition). Presses universitaires de France.

Barney, J. (1991). Firm resources and sustained competitive advantage. Journal of Management, 17(1), 99-120.

Barzi, R. (2011). SMEs and organizational agility: An exploratory study. Revue Innovations, 2(35), 2945.

Baum, J.R., Locke, E.A., \& Smith, K.G. (2001). A multidimensional model of venture growth. Academy of Management Journal, 44(2), 292-303.

Beyer, F.M. (2010). Coaching, an impossible job? Paris, Armand Colin.

Brouard, F. (2007). Une recherche-action pour diagnostiquer les pratiques de veille stratégique des PME. Revue internationale PME: Économie et Gestion de la Petite et Moyenne Entreprise, 20(1), 9-40.

Bryan, L., \& Farrell, D. (2009). Benchmarks for leadership in uncertain times. The Expansion Management Review, (1), 60-69.

Cameron, K.S., Kim, M.U., \& Whetten, D.A. (1987). Organizational effects of decline and turbulence. Administrative Science Quarterly, 32, 222-240.

Chabaud, D., \& Sammut, S. (2016). Le dirigeant au cœur des dynamiques entrepreneuriales des PME. Revue de l'Entrepreneuriat, 15(1), 7-13.

Choucair, M. (2012). La PME: Développement et emploi. Econews Bulletin of the Lebanese and Arab Economy, 15.

Corm, G. (2004). Lebanon's economic situation and its development prospects in the region. Confluences Méditerranée, 49.

Couland, J. (2005). L'exception libanaise: Confessionnalisme et laïcité. La Pensée, 342, 135-145.

Coutu, D.L. (2002). How resilience works. Harvard Business Review, 80(5), 46-56. 
Crutzen, N., \& Van Caillie, D. (2010). Towards a Taxonomy of Explanatory Failure Patterns for Small Firms: A Quantitative Research Analysis. Review of Business and Economic Literature, 55(4), 438-463.

De Peretti, A.D., Legrand, J.A., \& Boniface, J. (2013). Encyclopedia of evaluation in training and education: A practical guide. Pedagogies, References, pp. 1158-4580.

Desquilbet, J.B. (2007). The constraints of Lebanese monetary policy (1993-2004): Public debt, dollarization and fixed exchange rate. L'Actualité économique, 83(2), 163-199.

Dugré, C. (2011). Les 13 Signes avant-coureurs de la crise. Québec, Benjamin Livre.

Durand, T. (2006). The alchemy of competence. Revue Française de Gestion, (1), 261-292.

Eisenhardt, K.M., \& Martin, J.A. (2000). Dynamic capabilities: What are they? Strategic Management Journal, pp. 1105-1121.

El-Ezzi, G. (2003). La reconstruction du Liban... un chantier semé d'embûches. Confluences Méditerranée, 47, 10. Retrieved from http://www.ifrance.com/Confluences/numeros/47.htmpitfalls

El-Khoury, G. (2011). The resilience of Lebanese banks: Analysis of some aspects of risk management under the Basel Accord (Doctoral dissertation, University of Liège, Liège, Belgium).

Emery, F.E., \& Trist, E.L. (1965). The causal texture of organizational environments. Human Relations, $18(1), 21-32$.

Fauvy, S. (2009). The instrumentalization of organizational competencies: An analysis of the identification and evolution of strategic competencies. Le cas de France Télécom. $\mathrm{PhD}$ thesis from the University of Angers.

Fayad, A. (2008). What does the Lebanese specificity mean? Supplement to L'ORIENT-LE JOUR: Réinventer le Liban, 74.

Fonrouge, C. (2002). The entrepreneur and his company: A dialogical relationship. Revue Française de Gestion, 28(138), 145-158.

Foss, N.J., \& Ishikawa, I. (2007). Towards a dynamic resource-based view: Insights from Austrian capital and entrepreneurship theory. Organization Studies, 28(5), 749-772.

Gueguen, G. (2001, June). Orientations stratégiques de la PME et influence de l'environnement: Entre déterminisme et voluntarisme. In 10th International Conference on Strategic Management (AIMS). Quebec, Canada.

Hamdan, K. (2004). Micro and Small Enterprises in Lebanon. Paper presented at the Economic Research Forum (ERF). Research report series.

Hamel, G., \& Prahalad, C.K. (1995). Conquering the future: Bold strategies to take control of your industry's future and create tomorrow's markets. Inter Éditions.

Helfat, C.E., Finkelstein, S., Mitchell, W., Peteraf, M., Singh, H., Teece, D., \& Winter, S.G. (2009). Dynamic capabilities: Understanding strategic change in organizations. John Wiley et Sons.

Jaouen, A. (2010). Typologie de dirigeants de très petite entreprise. Journal of Small Business and Entrepreneurship, 23(1), 133-152.

Johnson, G., Whittington, R., Scholes, K., \& Frery, F. (2011). Strategic (9th edition). Paris: Pearson Education.

Julien, P-A. (1997). Pour une définition des PME. In P-A. Julien (Dir.), Les PME: Bilan et perspectives (pp. 1-43). Paris, Economica.

Julien, P-A., \& Carrier, C. (2002). Innovation and SMEs. In P-A. Julien (Dir.), Les PME: Bilan et perspectives (3rd ed.). Presses Inter-Universitaires, Cap-Rouge (Québec).

Kotler, P., Keller, K.L., Ancarani, F., \& Costabile, M. (2014). Marketing management (14e). 14th Pearson.

Labaki, B., \& Rjeily, K.A. (1993). Bilan des guerres du Liban, 1975-1990. Editions L'Harmattan.

Lalonde, C. (2004). In search of archetypes in crisis management. Journal of Contingencies and Crisis management, 12(2), 76-88.

Lamoureux, A. (1995). Research and methodology in the social sciences and humanities. Laval, Quebec: Éditions Études Vivantes.

116 Journal of Applied Business and Economics Vol. 23(5) 2021 
Le Boulaire, M., \& Retour, D. (2008). Competency management, strategy and business performance: What is the role of the HR function? Revue de Gestion des Ressources Humaines, 70, 51-68.

Lee, D.Y., \& Tsang, E.W. (2001). The effects of entrepreneurial personality, background and network activities on venture growth. Journal of Management Studies, 38(4), 583-602.

Lefebvre, E. (1991). Profil distinctif des dirigeants de PME innovantes. Revue Internationale PME: Économie et Gestion de la Petite et Moyenne Entreprise, 4(3), 7-26.

Lesca, H. (2008). Governance of an organization: Anticipating or anticipating? La Revue des Sciences de Gestion, (3), 11-17.

Levratto, N., \& Ramadan, M. (2009). Internationalization of SMEs in developing countries: A conceptual model of Lebanese SMEs. 11th Scientific Days of the Entrepreneurship Network, INRPME-AUFAIREPME. Trois-Rivières, Canada.

Levratto, N. (2009). SMEs: Definition, economic role and public policies. De Boeck Superior.

Marchesnay, M. (2000). L'entrepreneur face à ses risques. Revue Innovation, Notebooks.

Marchesnay, M. (2008). Proximités et singularités des TPE. In A. Jaouen \& O. Torrès (Dir.), Les très petites entreprises : Un management de proximité (pp. 81-103), Paris, Hermès Lavoisier.

Martin, C. (2008). Contribution à la définition d'actions pour la pérennisation de la prévention des risques professionnels dans les PME-PMI. PhD thesis of the École Nationale Supérieure des Mines de Paris.

Mayer, R., \& Deslauriers, J-P. (2000). Some elements of qualitative analysis: Content analysis, anchored analysis, analytical induction and life story. Méthodes de Recherche en Intervention Sociale, p.165.

Meier, O., \& Pacitto, J.C. (2007). The return of the actor or the "good reasons" for the behaviour of managers in very small firms. Proceedings of the 5th IAE International Congress.

Mercuri, S., \& Raiis, M. (2010). Strategic alliance between SMEs and large international firms: What role for the middle manager? In Congrès Internationalisation des PME (iPME): Internationalization of SMEs: From Global SMEs to Born Global Firms (p.27).

Miles, M.B., \& Huberman, A.M. (2003). Analysis of qualitative data. De Boeck Superior.

Mucchielli, A. (2005). The development of qualitative methods and the constructivist approach to human phenomena. Recherches qualitatives Hors-série "Les Actes ", 1, 41-60.

Peretti, J.M., \& Swalhi, A. (2007). Measuring organizational loyalty. Proceedings of the 18th Congress of the AGRH.

Pettersen, N., St-Pierre, J., \& Brutus, S. (2011). Relationship between the skills of SME managers and their company's performance: Contribution of a multisource measurement tool. International Journal SME: Economics and Management of Small and Medium-Sized Enterprises, 24(1), 167193.

Pinel, W., \& Robert, B. (2009). Organizational resilience: Training concepts and activities. MA Sc. Thesis, École Polytechnique de Montréal, PQ, Canada.

Prévot, F., Brulhart, F., \& Guieu, G. (2010). Resource-based perspectives. Revue Française de Gestion, (5), 87-103.

Puthod, D., \& Thévenard-Puthod, C. (2006). Cooperation, tensions and conflict in an innovation network built around an SME. Revue Française de Gestion, (5), 181-204.

Ramadan, M., \& Levratto, N. (2011). Conceptualizing the internationalization of SMEs: An application to the case of Lebanon. International Review SME: Economics and Management of Small and Medium Enterprises, 24(1), 71-106.

Raveleau, B. (2007). La dynamique de l'activité des dirigeants de PME. Proceedings of the 5econgrès International de l'Académie de l'Entrepreneuriat. Sherbrooke.

Raymond, L., \& St-Pierre, J. (2005). Antecedents and performance outcomes of advanced manufacturing systems sophistication in SMEs. International Journal of Operations et Production Management, 25(6), 514-533.

Sadler-Smith, E., Hampson, Y., Chaston, I., \& Badger, B. (2003). Managerial behavior, entrepreneurial style, and small firm performance. Journal of Small Business Management, 41(1), 47-67. 
Saives, A.L., Desmarteau, R.H., \& Kerzazi, L. (2011). Business models, proximity and territorialization of firms. Revue Française de Gestion, (4), 57-75.

Salloum, L. (2015). Family businesses: Acquisition of managerial and organizational shareholdings on performance. Bart and Jones Publishers.

Saporta, B. (1986). Strategies for the SME. Paris: Montchrestien.

Sherehiy, B., \& Karwowski, W. (2014). The relationship between work organization and workforce agility in small manufacturing enterprises. International Journal of Industrial Ergonomics, 44(3), 466-473.

Smart, C., \& Vertinsky, I. (1984). Strategy and the environment: A study of corporate responses to crises. Strategic Management Journal, 5(3), 199-213.

Smith, J.A., \& Osborn, M. (2003). Interpretative phenomenological analysis. Qualitative psychology: A practical guide to research methods (pp. 51-80). New york: Guilford Press.

Sogbossi, B. (2012). Decision-making by Small Business Leaders in the face of a complex environment: Intuition as a strategic alternative. Proceedings of the $11^{\text {th }}$ CIFEPME.

St-Pierre, J., Audet, J., \& Mathieu, C. (2003). Les nouveaux modèles d'affaires des PME manufacturières: Une étude exploratoire. Institut de Recherche sur les PME, 3, 1-4. Canada. Université du Québec à Trois-Rivières.

Sull, D. (2010, December). Competing through organizational agility. McKinsey Quarterly, pp. 48-56.

Teece, D.J. (2007). Explicating dynamic capabilities: The nature and micro foundations of (sustainable) enterprise performance. Strategic Management Journal, 28(13), 1319-1350.

Torrès, O. (2007). Descriptive approach to the specificity of SME management: The proximity mix. In L.J. Filion (Dir.), Management des PME, de la création à la croissance (pp. 23-34). Editions du Renouveau Pédagogique.

Torrès, O. (2002). Small firm, globalization strategy and proximity. Research in Entrepreneurship and Small Business, 16, 1-12.

Torrès, O., \& Jaouen, A. (2008). Les très petites entreprises, un management de proximité. Hermès Lavoisier, pp. 27-55.

Ulrich, D., Younger, J., \& Brockbank, W. (2008). The twenty-first-century HR organization. Human Resource Management, 47(4), 829-850.

Weitzel, W., \& Jonsson, E. (1989). Decline in organizations: A literature integration and extension. Administrative Science Quarterly, pp. 91-109.

Zinnbauer, D., Dobson, R., \& Despota, K. (2009). Global Corruption Report 2009: Corruption and the private sector. Burgundy Report, Transparency International and Ernst and Young, Cambridge University Press.

\section{APPENDIX 1. THE MAINTENANCE GUIDE}

\section{Identification of the SME}

Corporate Identity:

- Creation date

- Who owns the company and since when?

- Sector of activity

- Number of employees (Determination of the type of company: medium, small or very small company)

- Are you a certified company?

- Approximate revenues

- $\quad$ R\&D budget (\% of revenue)

- The company's subsidiaries 
Production:

- (Type of production: production of goods or services, identify the product or range of products, destination of the products).

Description of the company:

- Deterioration of buildings and equipment (their productive capacity)

- Technology: obsolete or state-of-the-art;

- Specify the role and importance of the various departments and services as well as the functions of the company: general management, production, human resources management, accounting, sales, etc.

\section{Presentation of the leader}

- Who runs the company? Identification of the manager(s) of the company (according to their notoriety and their positions). Do you have a board of directors? Are its members family members? Do they have expertise in the field? Meetings? How do you coordinate with this board?

- Age, education and level of training.

\section{Dynamics of the contribution of managerial practices to strengthening the resilience of the SME in a turbulent context}

- Brief history of the company: its evolution in its environment on the one hand, in terms of location, products, composition and dynamism of the team, dominant culture, on the other hand, in terms of employment and turnover (growth indicators).

- You run a company that dates back to the year.... and has managed to survive more than 15 years of civil war. What is your secret?

- How is decision making done in such a context?

- Do you favour consultation, discussion and negotiation rather than individual decisionmaking?

- How do you maintain your authority over the company and its evolution? (proximity)

- Do you use business practices that you consider innovative/original (that differentiate you from others)?

- In the positive case, what are these practices and what are the problems encountered in their adoption, is there a specific budget allocated (\% of turnover)?

- Can you describe your relationships with other companies? What are they like? Regular, formal, non-formal (intuitive), etc. (Networked companies)

- What resources do you consider important for your company in such a context? Can you list them in order of importance.

- By taking all the resources mentioned:

- Which ones are rare?

- Which ones are yours? Are you dependent on another company that provides you with an essential (critical) resource or do you always find alternative sources of supply?

- In such a context, what are the skills that you consider indispensable and that you seek to develop in your employees (How do you improve their performance)?

- What are the routines (tricks) implemented that differentiate you from other companies?

- Do you have strategic action plans or pre-established scenarios to accompany the period of disruption?

- Do you develop solutions from situations that have threatened your business?

- What do you think are the main reasons for the survival of your business? 
- What is your vision for the future? What are your ambitions and what is the possibility of realizing them?

General questions: (These questions are not necessarily asked of all leaders but of some, and this according to certain specific answers)

- You are the number one company in Lebanon in .......What's the reason?

- Are there any aspects that we did not cover in this interview that you find useful for understanding the problem? Could you give me your comments and/or suggestions related to this interview and the way it was conducted?

\section{APPENDIX 2. DETAILED DESCRIPTION OF THE MANAGERS OF THE SAMPLED SMES / LOCATION OF THE SAMPLED SMES / SECTOR OF ACTIVITY TO WHICH THE SAMPLED SMES BELONG}

N.B. Business manager or business leader means the person who is at the head of a business, without necessarily being the founder or owner of the business. He or she manages the business according to the powers granted to him or her.

$\mathrm{M}=$ Male

$\mathrm{F}=$ Female

F.M. = Founding Manager of the company (entrepreneur)

M.O. = Owner-Manager or Co-Owner-Manager of the business without having founded it (inheritance or buyout)

G.M. = General Manager (not founder or owner of the company)

TABLE 16

DETAILED DESCRIPTION OF THE MANAGERS OF THE SAMPLED SMES

\begin{tabular}{|c|c|c|c|c|c|c|c|}
\hline $\begin{array}{l}\text { Manager } \\
\text { No. }\end{array}$ & $\begin{array}{l}\text { Creation } \\
\text { date }\end{array}$ & $\begin{array}{l}\text { Location } \\
\text { (governorate) }\end{array}$ & Status & Management & $\begin{array}{l}\text { Approximate } \\
\text { age of } \\
\text { executive } \\
\text { interviewed }\end{array}$ & Gender & Staff \\
\hline 10 & 1967 & South Lebanon & $\begin{array}{l}\text { F.M. } \\
+ \\
\text { O.M. }\end{array}$ & $\begin{array}{l}\text { Manager + } \\
\text { brother }\end{array}$ & $\begin{array}{l}55-75 \text { years } \\
\text { old }\end{array}$ & $\mathbf{M}$ & 53 \\
\hline 15 & 1956 & Beqaa & O.M. & $\begin{array}{l}\text { Leader at the } \\
\text { head of the SME }\end{array}$ & $35-55$ years & $\mathbf{M}$ & 33 \\
\hline 3 & 1974 & $\begin{array}{l}\text { Beirut and } \\
\text { Mount } \\
\text { Lebanon } \\
\end{array}$ & O.M. & $\begin{array}{l}\text { Manager + } \\
\text { brother }\end{array}$ & 35-55 years & $\mathbf{M}$ & 51 \\
\hline 1 & 1970 & North Lebanon & O.M. & Manager + wife & $35-55$ years & $\mathbf{F}+\mathbf{M}$ & 75 \\
\hline 5 & 1969 & Beqaa & G.M. & $\begin{array}{l}\text { Leader at the } \\
\text { head of the SME }\end{array}$ & $35-55$ years & $\mathbf{F}$ & 27 \\
\hline 4 & 1967 & $\begin{array}{l}\text { Beirut and } \\
\text { Mount } \\
\text { Lebanon }\end{array}$ & G.M. & $\begin{array}{l}\text { Leader at the } \\
\text { head of the SME }\end{array}$ & $\begin{array}{l}55-75 \text { years } \\
\text { old }\end{array}$ & $\mathbf{M}$ & 54 \\
\hline 13 & 1935 & North Lebanon & G.M. & $\begin{array}{l}\text { Leader at the } \\
\text { head of the SME }\end{array}$ & $35-55$ years & $\mathbf{M}$ & 42 \\
\hline 11 & 1900 & $\begin{array}{l}\text { Beirut and } \\
\text { Mount } \\
\text { Lebanon }\end{array}$ & $\begin{array}{l}\text { O.M. } \\
+ \\
\text { O.M. }\end{array}$ & $\begin{array}{l}\text { Manager + } \\
\text { father }\end{array}$ & $35-55$ years & $\mathbf{M}$ & 29 \\
\hline
\end{tabular}




\begin{tabular}{|c|c|c|c|c|c|c|c|}
\hline 6 & 1928 & $\begin{array}{l}\text { Beirut and } \\
\text { Mount } \\
\text { Lebanon }\end{array}$ & G.M. & $\begin{array}{l}\text { Leader at the } \\
\text { head of the SME }\end{array}$ & $\begin{array}{l}\text { 55-75 years } \\
\text { old }\end{array}$ & $\mathbf{M}$ & 65 \\
\hline 7 & 1958 & South Lebanon & O.M. & $\begin{array}{l}\text { Leader at the } \\
\text { head of the SME }\end{array}$ & $\begin{array}{l}55-75 \text { years } \\
\text { old }\end{array}$ & $\mathbf{M}$ & 17 \\
\hline 2 & 1962 & North Lebanon & O.M. & $\begin{array}{l}\text { Leader at the } \\
\text { head of the SME }\end{array}$ & $35-55$ years & $\mathbf{M}$ & 36 \\
\hline 12 & 1876 & $\begin{array}{l}\text { Beirut and } \\
\text { Mount } \\
\text { Lebanon }\end{array}$ & G.M. & $\begin{array}{l}\text { Leader at the } \\
\text { head of the SME }\end{array}$ & $\begin{array}{l}55-75 \text { years } \\
\text { old }\end{array}$ & $\mathbf{M}$ & 56 \\
\hline 8 & 1970 & $\begin{array}{l}\text { Beirut and } \\
\text { Mount } \\
\text { Lebanon }\end{array}$ & F.M. & $\begin{array}{l}\text { Leader at the } \\
\text { head of the SME }\end{array}$ & $\begin{array}{l}\text { 55-75 years } \\
\text { old }\end{array}$ & $\mathbf{M}$ & 18 \\
\hline 9 & 1972 & $\begin{array}{l}\text { Beirut and } \\
\text { Mount } \\
\text { Lebanon }\end{array}$ & F.M. & $\begin{array}{l}\text { Leader at the } \\
\text { head of the SME }\end{array}$ & $\begin{array}{l}\text { 55-75 years } \\
\text { old }\end{array}$ & $\mathbf{M}$ & 25 \\
\hline 14 & 1968 & $\begin{array}{l}\text { Beirut and } \\
\text { Mount } \\
\text { Lebanon }\end{array}$ & G.M. & $\begin{array}{l}\text { Leader at the } \\
\text { head of the SME }\end{array}$ & $35-55$ years & $\mathbf{M}$ & 81 \\
\hline
\end{tabular}

TABLE 17

LOCATION OF THE SAMPLED SMES

\begin{tabular}{|c|c|c|c|c|}
\hline \multicolumn{4}{|c|}{ Geographical distribution of Lebanese SMEs in 2006} & \multirow{2}{*}{$\begin{array}{l}\text { The } \\
\text { location of } \\
\text { the sampled } \\
\text { SMEs }\end{array}$} \\
\hline & Number & $\%$ & & \\
\hline Beirut & 25504 & $14,50 \%$ & \multirow{3}{*}{$51 \%$} & \\
\hline Mount Lebanon & 64265 & $36,50 \%$ & & 8 \\
\hline North Lebanon & 33985 & $19,25 \%$ & & 3 \\
\hline South Lebanon & 29480 & $16,75 \%$ & & 2 \\
\hline Beqaa & 23045 & $13 \%$ & & 2 \\
\hline Total & 176279 & $100 \%$ & & 15 \\
\hline
\end{tabular}

TABLE 18

SECTORS OF ACTIVITY TO WHICH THE SAMPLED SMES BELONG

\begin{tabular}{|l|l|l|l|l|c|}
\hline No & $\begin{array}{l}\text { The economic activities of } \\
\text { Lebanese companies }\end{array}$ & $\begin{array}{l}\text { The \% } \\
\text { distribution of } \\
\text { Lebanese } \\
\text { companies by } \\
\text { activity }\end{array}$ & $\begin{array}{l}\text { The } \\
\text { constitution } \\
\text { of our } \\
\text { sample }\end{array}$ & $\begin{array}{l}\text { P (producing } \\
\text { company) } \\
\text { D } \\
\text { (distributing } \\
\text { company) }\end{array}$ & Login \\
\hline 1 & Food and Beverages & $4,7 \%$ & $\mathbf{1}$ & $\mathrm{P}$ & $\mathrm{N} 10$ \\
\hline 2 & Textile and leather & $1,72 \%$ & $\mathbf{1}$ & $\mathrm{P}$ & $\mathrm{N} 15$ \\
\hline 3 & $\begin{array}{l}\text { - Paper and cardboard } \\
\text { - Printing and publishing } \\
\text { - Non-metallic products } \\
\text { - Metal products }\end{array}$ & $3,5 \%$ & $\mathbf{1}$ & $\mathrm{P}$ & $\mathrm{N} 3$ \\
\hline 4 & & & $\mathrm{P}$ & $\mathrm{N} 1$ \\
\hline
\end{tabular}




\begin{tabular}{|c|c|c|c|c|c|}
\hline 5 & $\begin{array}{l}\text { - Equipment and tools } \\
\text { - Furniture }\end{array}$ & $3,15 \%$ & 1 & $\mathrm{D}$ & N5 \\
\hline 6 & $\begin{array}{l}\text { - Water, Electricity and gas } \\
\text { - Buildings and construction }\end{array}$ & $1,46 \%$ & 1 & $\mathrm{P}$ & N4 \\
\hline 7 & $\begin{array}{l}\text { Sale and maintenance of all } \\
\text { vehicles }\end{array}$ & $11,45 \%$ & 1 & $\mathrm{D}$ & N13 \\
\hline 8 & Wholesale trade & $3,5 \%$ & 1 & $\mathrm{D}$ & N11 \\
\hline 9 & Retail Trade & $43,88 \%$ & 2 & $\mathrm{D}$ & N6 and N7 \\
\hline 10 & Hotels and restaurants & $3,87 \%$ & 1 & $\mathrm{D}$ & $\mathrm{N} 2$ \\
\hline 11 & $\begin{array}{l}\text { - Transport and activities ancillary } \\
\text { to transport }\end{array}$ & $1,23 \%$ & & & \\
\hline 12 & Post and telecom & $0,30 \%$ & & & \\
\hline 13 & $\begin{array}{l}\text { - Financial intermediation } \\
\text { - Insurance }\end{array}$ & $1,12 \%$ & 1 & $\mathrm{D}$ & N12 \\
\hline 14 & Real estate activities & $0,35 \%$ & & & \\
\hline 15 & $\begin{array}{l}\text { - Rental of equipment and tools } \\
\text { - IT, R\&D services }\end{array}$ & $4,15 \%$ & & & \\
\hline 16 & Teaching - Training & $0,95 \%$ & & & \\
\hline 17 & Health and Social Action & $4,90 \%$ & 1 & $\mathrm{D}$ & N8 \\
\hline 18 & $\begin{array}{l}\text { - Societal and social service } \\
\text { activities } \\
\text {-Entertainment, cultural and } \\
\text { sporting activities }\end{array}$ & $2,55 \%$ & 1 & $\mathrm{D}$ & N9 \\
\hline 19 & Services to individuals & $5,47 \%$ & 1 & $\mathrm{D}$ & N14 \\
\hline Total & & $100 \%$ & 15 & & \\
\hline
\end{tabular}

\section{APPENDIX 3. EXAMPLES OF CODING AND CATEGORIZATION}

\section{The Coding}

Identified codes:

- Company increasingly specialized in its field

- Create a specific image based on research rather than industry

\section{Raw Fragment Taken From the E6 Maintenance}

The image of the future that we seek to develop is that of a company specialized in its field much more than services. In the field of health, we are trying to create a health image of the company more than an industrial image, we want to move away from the industrial to the health field (....). Health i.e. home care, patients, more services in hospitals. We are in the process of creating sleep laboratories that we manage inside the hospital to analyze all sleep problems, so we want to move towards more specialization and towards a "medicalized" image (Case E6/ L662-671).

\section{Categorization}

The categorization step, i.e. the grouping of codes related to the same category, was performed (for example, codes such as "Despite the situation, buy machines", "Despite the situation, make a new investment" were grouped into the category: "Act risky").

The realisation of code groupings is the basis for putting the results into perspective. In the table below, we explain by an example how we proceeded in the categorization step. 
TABLE 19

EXAMPLE ILLUSTRATING THE GROUPING OF CODES

\begin{tabular}{|c|c|c|c|}
\hline \multicolumn{4}{|c|}{ CODES identified and taken from the speeches of the leaders } \\
\hline $\begin{array}{l}\text { "In spite of the } \\
\text { situation, buy new } \\
\text { machines". }\end{array}$ & $\begin{array}{l}\text { "Despite the situation, } \\
\text { achieving a } \\
\text { new } \\
\text { investment". }\end{array}$ & "Overcoming Fear" & "Escaping threats" \\
\hline \multicolumn{2}{|c|}{ Grouping of codes into CATEGORIES } & \multicolumn{2}{|c|}{ Grouping of codes into CATEGORIES } \\
\hline Acting risky & & \multicolumn{2}{|c|}{ Acting to circumvent fear of the unknown } \\
\hline \multicolumn{4}{|c|}{ SUB-THEME } \\
\hline \multicolumn{4}{|c|}{ Reactive driving } \\
\hline \multicolumn{4}{|c|}{ THEME } \\
\hline \multicolumn{4}{|c|}{ Acting conditioned by the personality of the leader } \\
\hline
\end{tabular}

\section{APPENDIX 4. THE FINAL ANALYSIS GRID}

Managerial dynamics of SME managers in a turbulent context

Component 1. Decision-making in a turbulent context

Acting conditioned by the personality of the leader (Theme)

\section{REACTIVE DRIVING (Sub-theme)}

$\bigcirc$ Acting risky (category)

$\circ$ Acting to circumvent fear and the unknown (category)

\section{PRUDENT DRIVING(Sub-theme)}

○ Pending Decisions/Freezing (category)

- Acting under pressure, fearful and distrustful of the environment (category)

Use of a personalized relationship with employees

Use of the manager's personal skills

$\circ$ Management by intuition

- Manager with diverse abilities and multiple functions

- Innovative leader

- Foresight and vigilance

○ Wise mobilization of resources/have "the flair" of family

Component 2. Managerial practices vis-à-vis partners (internal and external)

Optimal use of employee performance

○ Implementation of productive and mobile multi-skilled teams

○ Employee Retention: Efforts focused on qualified and/or dedicated employees

$\underline{\text { Reaching customer satisfaction }}$

$\circ$ Building on previous experience with former clients

- Concern for improving the quality of products/services

- Adjusting to the changing business environment: concessions

Working in networks/networking

○ Friendly relations

○ Professional relations 


\section{Component 3. Resources essential to the SME's life-sustainability}

Activation of human resources (in-house)

EXPERIENTIAL TECHNICAL QUALIFICATIONS (know-how)

$\circ$ Use of operational, open and creative profile

INTERPERSONAL QUALIFICATIONS / COMMUNICATION (life skills)

- Use of the profile capable of showing positive spirit and solidarity

Activation of financial resources

$\circ$ Protection through the availability of cash

- Granting of pre-negotiated loans (cold)

Activation of practices essential to the survival of the SME

$\circ$ Alliance with international companies

- Breakthrough in local or international markets

$\circ$ Breakthrough in new professions

\section{Component 4. Essential Skills for Complex Environments}

The reputation of the SME

- Saving your image

- Credibility support

Manager able to mobilize and develop his human resources

- Ability to keep employees informed and involved

- Ability to reinforce the sense of belonging of its employees

Flexible SME

Projection into the future

\section{DISCRETE OR SHORT-TERM PLANNING}

$\circ$ Strengthening market presence

- Exploitation of the existing

LONG TERM PLANNING / ABILITY TO STEP BACK AND ANALYZE

- Projects embedded in quality-research-innovation

- Change of image/focus on specialization 